\title{
EVALUASI KEMAMPUAN PEMECAHAN MASALAH MATEMATIS MELALUI MODEL PEMBELAJARAN CREATIVE PROBLEM SOLVING PADA SISWA KELAS X SMA NEGERI KOTA JAMBI
}

\author{
Harman $^{6}$
}

\begin{abstract}
This study aims to determine the ability of solving mathematical problems through creative problem solving learning model higher than the direct learning model on the students of class $X$ state senior high school of Jambi city. This research is an experimental research because of causal relationship. The way this study is to compare one or more comparison group that have received treatment. The sample of this research is class X MIA 1 as experiment class which is taught by creative problem solving model, while control class is X MIA 2 which is taught by direct learning model. From the result of research and discussion that have been done can be concluded that the ability of solving mathematical problems of students who are studied through the creative problem solving (experiments) learning model obtained an average of 71,9 and students in the learning through direct learning model (control) average 63,3. Of the two clasess obtained $t_{\text {count }}$ is 4,17 and $t_{\text {table }}$ is 1,66 then in this case $H_{0}$ is rejected and $H_{1}$ accepted at $95 \%$ confidence level. Then it can be concluded that the problem solving ability of mathematical students taught through creative problem solving learning model is higher that the students taught through direct learning model in class X state senior high school of Jambi city.
\end{abstract}

Keywords: Mathematical Problem Solving Ability, Creative Problem Solving Learning Model, Direct Learning Model.

\section{PENDAHULUAN}

Pendidikan adalah usaha sadar yang dengan sengaja dirancang untuk mencapai tujuan yang telah ditetapkan. Pendidikan bertujuan untuk meningkatkan kualitas sumber daya manusia. Pendidikan juga merupakan salah satu hal penting untuk menentukan maju mundurnya suatu bangsa, maka untuk menghasilkan sumber daya manusia sebagai subyek dalam pembangunan yang baik, diperlukan modal dari hasil pendidikan itu sendiri. Salah satu usaha untuk meningkatkan kualitas sumber daya manusia ialah melalui proses pembelajaran disekolah.

\footnotetext{
${ }^{6}$ Dosen Pendidikan Matematika Universitas Batanghari
} 
Tujuan lain dari pendidikan yaitu untuk mewujudkan keinginan, kebutuhan, dan kemampuan individu. Pendidikan hendaknya mampu mengembangkan bakat yang dimiliki peserta didik secara optimal sehingga peserta didik dapat mengembangkan potensi diri yang dimilikinya menjadi suatu prestasi yang memiliki nilai jual.

Dalam dunia pendidikan telah kita ketahui salah satunya adalah pendidikan matematika yang diperkenalkan kepada siswa sejak tingkat Sekolah Dasar (SD) sampai ke perguruan tinggi. Matematika merupakan pola berfikir, pola mengorganisasikan dan pembuktian yang logis mengenai bentuk, susunan, besaran, dan konsep-konsep yang berhubungan dengan kehidupan sehari-hari. Sesuai dengan tujuan pendidikan yaitu salah satunya adalah untuk mewujudkan kemampuan individu, maka salah satu kemampuan yang ada pada pendidikan matematika adalah kemampuan pemecahan masalah matematis.

Suatu masalah biasanya memuat situasi yang mendorong seseorang untuk menyelesaikannya, akan tetapi tidak tahu secara langsung apa yang harus dikerjakan untuk menyelesaikannya. Memecahkan suatu masalah merupakan suatu aktivitas dasar bagi manusia (Hudoyo, 1979:156). Kenyataan menunjukkan, sebagian besar kehidupan kita adalah berhadapan dengan masalah-masalah. Kita perlu mencari penyelesainnya. Bila kita gagal dengan suatu cara untuk menyelesaikan suatu masalah, Kita harus mencoba menyelesaikannya dengan cara lain. Pemecahan masalah memberikan manfaat yang besar kepada siswa dalam melihat relevansi antara matematika dengan pelajaran lain, serta kehidupan nyata. Pemecahan masalah merupakan sarana sekaligus target dari pembelajaran matematika di sekolah. Sebagai sarana, pemecahan masalah memungkinkan siswa untuk mengkonstruksi ide-ide matematis. Di samping itu, suatu masalah dapat mengarahkan siswa untuk melakukan investigasi, mengeksplorasi pola-pola, dan berpikir secara kritis. Untuk memecahkan masalah, siswa perlu melakukan pengamatan yang cermat, membuat hubungan, bertanya, dan menyampaikan.

Kemampuan pemecahan masalah matematis merupakan kemampuan dimana siswa berupaya mencari jalan keluar yang dilakukan dalam mencapai tujuan, juga memerlukan kesiapan, kreativitas, pengetahuan dan kemampuan serta aplikasinya dalam kehidupan sehari-hari. Kemampuan pemecahan masalah matematis merupakan salah satu kemampuan yang harus dimiliki siswa, karena pemecahan masalah memberikan manfaat yang besar kepada siswa dalam melihat relevansi antara matematika dengan mata pelajaran lain, serta dalam kehidupan nyata. Siswa dikatakan mampu memecahkan masalah matematika jika mereka dapat memahami, 
memilih strategi yang tepat, kemudian menerapkannya dalam penyelesaian masalah. Kemampuan pemecahan masalah matematis juga sangat memicu hasil belajar matematika menjadi lebih baik dan juga merupakan tujuan umum pengajaran matematika, karena kemampuan pemecahan masalah matematis dapat membantu dalam memecahkan persoalan baik dalam pelajaran lain maupun dalam kehidupan sehari-hari.

Kemampuan pemecahan masalah matematis bukanlah kemampuan yang mudah dicapai, Permasalahan umum yang dihadapi oleh setiap jenjang pendidikan termasuk SMA adalah rendahnya hasil belajar siswa. Banyak faktor yang terkait di dalamnya seperti kurangnya penggunaan model pembelajaran pada guru yang mendukung setiap pokok bahasan pelajaran tersebut, sehingga kurang berkembangnya kemampuan-kemampuan yang ada di dalam diri siswa. kurangnya kemampuan pemecahan masalah matematis siswa juga menyebabkan proses belajar mengajar matematika itu tidak mencapai tujuan hasil belajar yang diharapkan.

Guru menjadi sorotan utama, sebab guru secara langsung yang dapat mempengaruhi, menilai dan mengembangkan kemampuan siswa untuk menjadi manusia cerdas, terampil dan bermoral. Oleh karena itu upaya untuk meningkatkan hasil belajar siswa tidak terlepas dari upaya kemampuan guru dalam mengajar dan penggunaan model dalam pembelajaran matematika. Bermacam-macam model pembelajaran telah diterapkan oleh para guru bidang studi matematika di sekolah-sekolah terhadap penyampaian konsep materi pelajaran, tetapi pemakaian model pembelajaran tersebut belum tentu mengkondisikan studi belajar dan hasil belajar yang baik.

Model pembelajaran yang banyak digunakan di sekolah adalah model pembelajaran yang mengacu pada gaya mengajar dimana guru terlibat aktif dalam mengusung isi pelajaran kepada peserta didik dan mengajarkannya secara langsung kepada seluruh kelas. Di sini peran dari guru memang sangat penting sebagai penyampai informasi, guru lebih dapat mengendalikan isi materi dan urutan informasi yang diterima oleh siswa. Guru menjelaskan materi dari awal sampai akhir pelajaran dan disertai dengan contoh soal, kemudian siswa diberikan beberapa soal untuk latihan.

Peran siswa sangat kurang dalam proses pembelajaran, karena pembelajaran yang berlangsung lebih berpusat pada guru dan komunikasi satu arah sehingga membuat siswa merasa kurang termotivasi karena kurangnya keaktifan mereka dikelas. Siswa lebih banyak mendengarkan dan mencatat apa yang disampaikan oleh guru. Kurangnya kemampuan pemecahan masalah matematis siswa di SMA Negeri Kota Jambi dalam belajar matematika tidak bisa dibiarkan begitu saja, karena dapat berpengaruh buruk terhadap siswa itu 
sendiri. Untuk menyelesaikan masalah tersebut, maka diperlukan suatu upaya untuk membuat suasana pembelajaran lebih menarik dan menyenangkan, dengan cara siswa diberi kesempatan untuk mengembangkan kemampuannya dalam kegiatan belajar.

Salah satu upaya yang ingin diterapkan peneliti untuk mengatasi permasalahan ini ialah dengan menerapkan model pembelajaran Creative Problem Solving. Model pembelajaran Creative problem solving merupakan model pembelajaran pemecahan masalah secara kreatif, guru bertugas untuk mengarahkan upaya pemecahan masalah secara kreatif dan juga menyediakan materi pelajaran atau topik diskusi yang dapat merangsang siswa untuk berpikir kreatif dalam memecahkan masalah. Model pembelajaran ini juga berkaitan dengan kemampuan pemecahan masalah matematis. Menurut Suryosubroto model pembelajaran Creative Problem Solving dibangun atas tiga macam komponen, yaitu ketekunan, masalah dan tantangan. Selain itu model pembelajaran Creative Problem Solving bertujuan untuk mengembangkan pemikiran divergen, berusaha mencapai berbagai alternatif dan memecahkan suatu masalah.

Model pembelajaran merupakan suatu perancanaan atau suatu pola yang digunakan sebagai pedoman dalam merencanakan pembelajaran dalam tutorial (Trianto, 2007:1). Hal ini senada dengan pendapat Shoimin (2014:23) model pembelajaran adalah kerangka konseptual yang melukiskan prosedur yang sistematis dalam mengorganisasikan pengalaman belajar untuk mencapai tujuan tertentu, dan berfungsi sebagai pedoman bagi para perancang pembelajaran dan para pengajar dalam merencanakan aktivitas belajar. Hal ini berarti model pembelajaran memberikan kerangka dan arah bagi guru untuk mengajar. Dari beberapa pandangan tersebut dapat disimpulkan, model pembelajaran adalah kerangka konseptual yang menggambarkan prosedur sistematik dalam mengorganisasikan pengalaman belajar untuk mencapai tujuan belajar.

Berdasarkan uraian di atas maka penulis akan melakukan penelitian yang berjudul "Evaluasi Kemampuan Pemecahan Masalah Matematis melalui Model Pembelajaran Creative Problem Solving pada Siswa Kelas X SMA Negeri Kota Jambi”.

\section{METODE PENELITIAN}

Penelitian ini merupakan penelitian eksperimen karena adanya hubungan sebab akibat. Cara penelitian ini adalah dengan membandingkan satu atau lebih kelompok pembanding yang telah menerima perlakuan. Penelitian eksperimen ini menggunakan bentuk quasi experimental design. Menurut Sugiyono (2007:77) quasi experimental design adalah desain penelitian yang mempunyai kelompok kontrol, tetapi tidak dapat berfungsi sepenuhnya untuk 
mengontrol variabel-variabel luar yang mempengaruhi pelaksanaan eksperimen.

Penelitian ini dilakukan pada dua kelas, yaitu kelas eksperimen dan kelas kontrol. Kelas eksperimen merupakan kelas yang diajarkan menggunakan model pembelajaran creative problem solving dan kelas kontrol merupakan kelas yang diajarkan menggunakan model pembelajaran langsung.

Menurut Maolani (2015:39), populasi adalah semua anggota dari suatu kelompok orang, kejadian, atau objek-objek yang ditentukan dalam suatu penelitian. Dalam penelitian ini yang akan dijadikan populasi adalah seluruh siswa kelas X MIA SMAN 9 Kota Jambi yang terdiri dari 3 kelas.

Sampel penelitian adalah sebagian dari populasi terjangkau yang memiliki sifat yang sama dengan populasi (Sudjana dan Ibrahim, 2009:85). Dalam penelitian ini sampel yang digunakan sebanyak dua kelas sampel yaitu kelas eksperimen dan kelas kontrol. Pengambilan sampel dalam penelitian ini menggunakan cara probability sampling. Dalam probability sampling elemen dalam populasi mempunyai peluang yang sama untuk menjadi sampel dan teknik yang digunakan yang digunakan dalam probability sampling adalah sampel acak atau random, yaitu teknik untuk mendapatkan sampel secara acak, dengan demikian setiap unit sampling sebagai unsur populasi memperoleh peluang yang sama untuk menjadi sampel. Cara yang digunakan dalam teknik acak atau random adalah dengan cara undian untuk menentukan dua sampel yang akan menjadi kelas eksperimen dan kelas kontrol. Undian yang terpilih pertama adalah kelas eksperimen dan yang terpilih kedua adalah kelas kontrol. Kelas eksperimen adalah kelas X MIA 1 yaitu kelas yang diajar dengan model pembelajaran creative problem solving, sedangkan kelas kontrol adalah kelas $\mathrm{X}$ MIA 2 yang diajar dengan model pembelajaran langsung.

Menurut Sugiyono (2007:243) dalam penelitian kuantiatif teknik analiasis data yang digunakan diarahkan untuk menjawab rumusan masalah atau menguji hipotesis yang telah dirumuskan dalam proposal. Dalam penelitian ini teknik analisis data dilakukan untuk mengetahui perbandingan kemampuan pemecahan masalah matematis siswa yang diajarkan dengan model pembelajaran creative problem solving dengan pembelajaran langsung pada siswa kelas X MIA SMA Negeri 9 Kota Jambi. Data yang dianalisis adalah skor hasil tes akhir siswa pada kelas sampel. Setelah data diperoleh, dilakukan analisis data untuk menguji hipotesis.

\section{HASIL DAN PEMBAHASAN}

Hasil-hasil penelitian yang disajikan dalam penelitian ini ada dua bagian, yaitu hasil penelitian yang diperoleh melalui analisis 
statistik deskritif dan analisis statistik inferensial. Analisis statistik deskriptif yang disajikan meliputi ukuran sampel, nilai rata-rata, nilai tertinggi, nilai terendah, simpangan baku, dan varians. Sedangkan analisis statistik inferensial meliputi uji normalitas, uji homogenitas, dan uji-t.

\section{A. Hasil Statistik Deskriptif}

Statistik deskriptif adalah statistik yang digunakan untuk menganalisis data dengan cara mendeskripsikan atau menggambarkan data yang telah terkumpul sebagaimana adanya tanpa bermaksud membuat kesimpulan yang berlaku untuk umum. Pada bagian ini dikemukakan karakteristik nilai dari masing-masing variabel penelitian. Karakteristik nilai kemampuan pemecahan masalah matematis siswa dapat dilihat dalam tabel 1 berikut ini.

Tabel 1. Karakteristik Nilai Dari Hasil Soal Post-test

\begin{tabular}{|c|c|c|}
\hline Statistik & Kelas Eksperimen & Kelas Kontrol \\
\hline Ukuran Sampel & 40 & 40 \\
\hline Rata-rata & 71,9 & 63,3 \\
\hline Nilai tertinggi & 90 & 80 \\
\hline Nilai terendah & 50 & 40 \\
\hline Simpangan Baku & 9,66 & 9,07 \\
\hline Varians & 93,47 & 82,42 \\
\hline
\end{tabular}

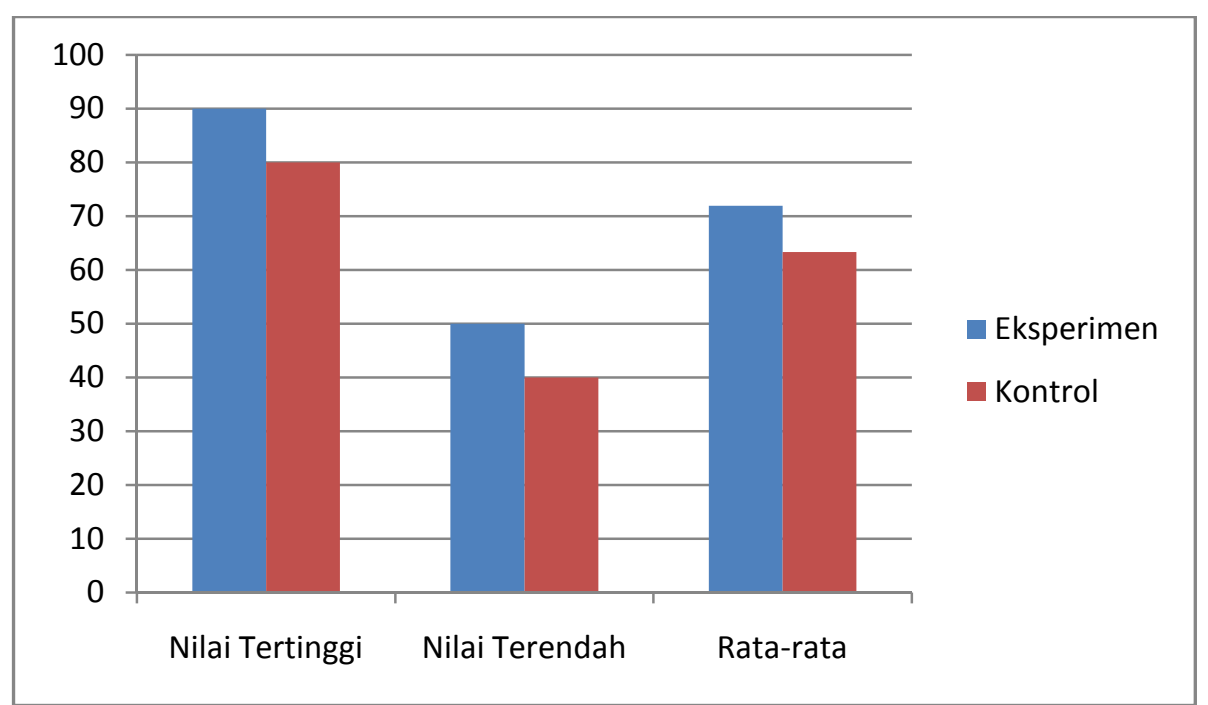

Gambar 1. Karakteristik Nilai Hasil Penelitian

Berdasarkan data di atas dapat dilihat bahwa rata-rata kemampuan pemecahan masalah pada kelas eksperimen yaitu 71,9 dengan nilai tertinggi 90 dan nilai terendah 50. Sedangkan, rata-rata hasil belajar pada kelas kontrol yaitu 63,3 dengan nilai tertinggi 80 dan nilai terendah 40. Selain itu juga dapat diketahui bahwa simpangan baku pada kelas eksperimen sebesar 9,66 dan pada kelas kontrol 9,07. 


\section{B. Hasil Analisis Inferensial}

Analisis ini bertujuan untuk mengetahui hasil tes kemampuan pemecahan masalah matematis siswa yang di belajarkan melalui model pembelajaran Creative Problem Solving dengan siswa yang di belajarkan melalui model pembelajaran langsung. Pengujian hipotesisnya dilakukan dengan menggunakan uji-t. Sebelum uji-t terlebih dahulu dilakukan uji normalitas dan uji homogenitas dari masing-masing kelas.

a. Menguji normalitas hasil tes kemampuan pemecahan masalah matematis siswa kelas eksperimen dan kelas kontrol.

Tabel 2. Hasil Uji Normalitas Soal Post-test

\begin{tabular}{|c|c|c|c|c|}
\hline $\begin{array}{c}\text { Kelas } \\
\text { Sampel }\end{array}$ & $\mathbf{D k}$ & $\boldsymbol{X}_{\boldsymbol{n}}^{\mathbf{Z}}$ & $\begin{array}{c}\boldsymbol{X}_{{ }_{\mathbf{H}}} \\
\boldsymbol{\alpha}=\mathbf{5 \%}\end{array}$ & $\mathbf{K e s i m p u l a n ~}$ \\
\hline Eksperimen & 3 & 3,61 & 7,81 & $\begin{array}{c}\text { Sampel berasal dari } \\
\text { populasi yang } \\
\text { berdistribusi normal }\end{array}$ \\
\hline Kontrol & 3 & 6,17 & 7,81 & $\begin{array}{c}\text { Sampel berasal dari } \\
\text { populasi yang } \\
\text { berdistribusi normal }\end{array}$ \\
\hline
\end{tabular}

Dari tabel 2. di atas terlihat bahwa $X_{\text {nit }}^{2} \quad<X_{\tau_{1}}^{2} \quad$ maka Ho diterima, sehingga dapat disimpulkan bahwa sampel berasal dari populasi berdistribusi normal.

b. Menguji homogenitas varians

Uji homogenitas post-test yang digunakan adalah uji F. Hasil homogenitas tes kemampuan pemecahan masalah matematis siswa di kelas eksperimen dan kelas kontrol dapat dilihat pada tabel 3. berikut:

Tabel 3. Hasil Uji Homogenitas Soal Post-test

\begin{tabular}{|c|c|c|c|c|c|}
\hline \multicolumn{2}{|c|}{ Varians } & \multirow{2}{*}{$\begin{array}{c}\text { Taraf } \\
\text { signifikan }\end{array}$} & \multirow[t]{2}{*}{$\mathbf{F}_{\mathrm{n}}$} & \multirow[t]{2}{*}{$\mathbf{F}_{\mathrm{t}}$} & \multirow[t]{2}{*}{ Keterangan } \\
\hline $\begin{array}{c}\text { Kelas } \\
\text { Eksperimen }\end{array}$ & $\begin{array}{c}\text { Kelas } \\
\text { Kontrol }\end{array}$ & & & & \\
\hline 93,48 & 82,42 & 0,05 & 1,13 & 1,65 & $\begin{array}{l}\text { Kedua sampel } \\
\text { mempunyai } \\
\text { varians yang } \\
\text { sama }\end{array}$ \\
\hline
\end{tabular}

Dari tabel di atas terlihat bahwa $\mathrm{F}_{\mathrm{h}}<\mathrm{F}_{\mathrm{ti}}$ maka Ho diterima, artinya kedua kelompok sampel mempunyai varians yang homogen pada tingkat kepercayaan $95 \%$.

c. Pengujian Hipotesis

Hasil yang diperoleh dari uji normalitas dan uji homogenitas menunjukkan bahwa kedua sampel berasal dari populasi yang berdistribusi normal dan mempunyai varians yang homogen, kemudian dilakukan uji hipotesis dengan menggunakan uji-t. 
Pengujian hipotesis dilakukan untuk mengetahui apakah hipotesis penelitian diterima atau ditolak.

Tabel 4. Hasil Uji-t Soal Post-test

\begin{tabular}{|c|c|c|c|}
\hline Dk & $\mathbf{t}_{\mathbf{n}}$ & $\mathbf{t}_{\mathbf{t}_{\mathbf{4}}}$ & Kesimpulan \\
\hline 78 & 4,17 & 1,66 & Tolak $\mathrm{H}_{0}$ dan terima \\
& & & $\mathrm{H}_{\mathbf{d}}$ \\
\hline
\end{tabular}

Dari perhitungan diperoleh nilai $\tau_{\text {nit }}$ sebesar 4,17 dan $t_{\tau_{1}}$ sebesar 1,66. Karena nilai $t_{\text {nit }}$ lebih besar dari pada $t_{t_{i}}$ maka $H_{0}$ ditolak dan $H_{1}$ diterima. Jadi, dapat disimpulkan bahwa rata-rata kemampuan pemecahan masalah yang diajarkan menggunakan model pembelajaran Creative Problem Solving lebih tinggi dari pada yang dibelajarkan dengan menggunakan model pembelajaran langsung.

Pada penelitian ini penulis menggunakan dua kelas sampel. Kelas pertama adalah kelas eksperimen dan kedua adalah kelas kontrol. Dalam pelaksanaannya, kelas eksperimen diberikan perlakuan model pembelajaran Creative Problem Solving dan kelas kontrol tetap pada keadaan biasanya yaitu dengan model pembelajaran langsung.

Pada proses pelaksanaan di kelas eksperimen, penulis menggunakan model pembelajaran Creative Problem Solving kepada siswa dalam melakukan pembelajaran materi Persamaan dan Pertidaksamaan Nilai Mutlak Satu Variabel. Selama proses pembelajaran di kelas eksperimen berlangsung siswa terlihat aktif dan memiliki rasa ingin tahu yang tinggi terhadap materi yang disampaikan. Siswa diikutsertakan dalam kegiatan praktek seperti menghitung bersama-sama dan sebagainya. Sehingga suasana kelas tidak kaku, proses pembelajaran lebih asik dan kreatif. Selanjutnya, kemampuan pemecahan masalah matematis siswa di kelas eksperimen terbukti lebih tinggi. Hal ini dapat dilihat pada pelaksanaan post-test. Siswa kelas eksperimen mampu mengerjakan soal dengan benar dan tepat. Sehingga nilai rata-rata dari keseluruhan siswa di kelas eksperimen memperoleh angka yang memuaskan.

Berbeda dengan kelas eksperimen, kelas kontrol diajarkan dengan model pembelajaran langsung. Selama proses pembelajaran siswa diajarkan dengan metode ceramah. Dengan bantuan buku paket yang diberikan kepada siswa, siswa memahami lalu mengerjakan soalsoal dalam buku tersebut. Proses pembelajaran dalam kelas kontrol lebih monoton. Penulis mengajarkan materi hanya satu arah. Sedikit sekali siswa yang aktif untuk memberikan umpan balik atas materi yang disampaikan. Dengan demikian guru kembali menerangkan materi yang sama. Sehingga proses pembelajaran yang diajarkan di kelas kontrol kurang efektif dan efisien.

Berdasarkan hasil post-test pada bahasan Persamaan dan Pertidaksamaan Nilai Mutlak Satu Variabel, kemampuan pemecahan 
masalah matematis siswa kelas eksperimen yang diajarkan dengan menggunakan model pembelajaran Creative Problem Solving yaitu 71,9 dengan nilai tertinggi 90 dan nilai terendah 50. Sedangkan, ratarata hasil belajar pada kelas kontrol yaitu 63,3 dengan nilai tertinggi 80 dan nilai terendah 40. Selain itu juga dapat diketahui bahwa simpangan baku pada kelas eksperimen sebesar 9,66 dan pada kelas kontrol 9,07.

Pengujian hipotesis dilakukan dengan menggunakan uji-t dan diperoleh nilai $t_{\text {nit }} \quad$ sebesar 4,17 dan $t_{\tau_{1}}$ sebesar 1,66. Terlihat nilai $t_{\text {nit }} \quad$ lebih besar dari $t_{\tau_{1}} \quad$ maka $H_{0}$ ditolak dan $H_{1}$ diterima. Sehingga penulis dapat menyimpulkan bahwa kemampuan pemecahan masalah matematis siswa yang diajarkan dengan menggunakan model pembelajaran Creative Problem Solving lebih tinggi dibandingkan kemampuan pemecahan masalah matematis siswa yang diajarkan dengan menggunakan model pembelajaran langsung.

\section{KESIMPULAN}

Dari hasil penelitian dan pembahasan yang telah dilakukan dapat disimpulkan bahwa: Kemampuan pemecahan masalah matematis siswa yang di belajarkan melalui model pembelajaran Creative Problem Solving (Eksperimen) memperoleh rata-rata 71,9 dan siswa yang di belajarkan melalui model pembelejaran langsung (kontrol) memperoleh rata-rata 63,3. Dari kedua kelas diperoleh $t_{\text {hitung }}$ $=4,17$ dan $\mathrm{t}_{\text {tabel }}=1,66$ maka dalam hal ini $\mathrm{H}_{0}$ ditolak dan $\mathrm{H}_{1}$ diterima pada tingkat kepercayaan 95\%. Maka dapat disimpulkan bahwa kemampuan pemecahan masalah matematis siswa yang di belajarkan melalui model pembelajaran Creative Problem Solving lebih tinggi dari pada siswa yang di belajarkan melalui model pembelajaran langsung di kelas X MIA SMA Negeri 9 Kota Jambi.

Siswa lebih memberikan respon positif terhadap pembelajaran matematika melalui model pembelajaran Creative Problem Solving Hal ini ditunjukkan dari tingginya nilai rata-rata kemampuan pemecahan masalah matematis siswa yang di belajarkan melalui model pembelajaran Creative Problem Solving dibandingkan dengan yang dibelajarkan melalui model pembelajaran langsung. 


\section{DAFTAR PUSTAKA}

Ardiansyah. 2008. "Studi Perbandingan Hasil Belajar Matematika Siswa yang Di Ajar Dengan Model Creative Problem Solving Menggunakan Media Video Compact Disk (VCD) dan Tidak Menggunakan Media Video Compact Disk (VCD) Di Kelas IV SD N 47 Kota Jambi”. Skripsi. Jambi : Fakultas Pendidikan Matematika Universitas Jambi.

Arifin, Zaenal. 2009. Evaluasi Pembelajaran. Bandung : Remaja Rosdakarya.

Arikunto, Suharsimi. 2009. Dasar-Dasar Evaluasi Pendidikan (Edisi Revisi). Jakarta: Bumi Aksara.

Dimyati dan Mudijono, 2009. Belajar dan Pembelajaran. Jakarta : PT Rineka Cipta.

Fauzan, Ahmad. 2011. Modul 1 Evaluasi Pembelajaran Matematika Pemecahan Masalah Matematis. Evaluasimatematika.net : Universitas Negeri Padang.

Hadis, Abdul. 2008. Psikologi dalam Pendidikan. Bandung : Alfabeta.

Huda, Miftahul. 2014. Model-Model Pengajaran dan Pembelajaran. Yoyakarta: Pustaka Belajar.

Hudoyo, Herman. 1979. Pengembangan Kurikulum Matematika dan Pelaksanaanya di Depan Kelas. Surabaya: Usaha Nasional.

Ihsan, Fuad. 2010. Dasar-Dasar Pendidikan. Jakarta : PT Rineka Cipta.

Margono. 2007. Metodelogi Penelitian Pendidikan. Jakarta : PT Rineka Cipta.

Muslich, Mansur. 2010. KTSP Dasar Pemahaman dan Pengembangan. Jakarta: Bumi Aksara.

Rizki, Shofrina. 2009. "Upaya Meningkatkan Aktivitas dan Hasil Belajar Fisika Siswa Dengan Menggunakan Model Pembelajaran Creative Problem Solving Berbasis Multimedia Di Kelas VIII E MTS Negeri Model Sungai Penuh". Skripsi. Jambi : Fakultas Pendidikan Fisika Universitas Jambi.

Rusman. 2014. Model-Model Pembelajaran Mengembangkan Profesionalisme Guru. Depok : PT Rajarafindo Persada.

Shoimin, Aris. 2014. 68 Model Pembelajaran Inovatif Dalam Kurikulum 2013. Yogyakarta : AR-Ruzz Media.

Sudijono, Anas. 2013. Pengantar Evaluasi Pendidikan. Jakarta : PT Raja Grafindo.

Sudjana. 2005. Metoda Statistika. Bandung : Trasito

Sudjana dan Ibrahim. 2009. Penelitian dan Penilaian pendidikan. Bandunng: Sinar Baru Algensindo.

Sugiyono. 2007. Metode Penelitian Kualitatif, Kuantitatif dan R\&D. Bandung: Alfabeta. 
Suprijono, Agus. 2010. Coperative Learning Teori dan Aplikasi PAIKEM. Yogyakarta : Pustaka Belajar.

Suryosubroto, B. 2009. Proses Belajar Mengajar di Sekolah (Edisi Revisi). Jakarta: PT Rineka Cipta.

Susanto. 2007. Pengembangan KTSP Dengan Prespektif Manajemen Visi. Yogyakarta: Matapena

Titarahardja dan Lasula. 2000. Pengantar Pendidikan. Jakarta : PT Rineka Cipta.

Trianto. 2007. Model Pembelajaran Terpadu dalam Teori dan Praktek. Jakarta: Prestasi Pustaka.

Uno, Hamzah. 2011. Perencanaan Pembelajaran. Jakarta : PT Bumi Aksara.

Yamin, Martinis. 2010. Strategi Pembelajaran Berbasis Kompetensi. Jakarta: Gaung Persada. 